\title{
Reflectance Characteristics of Silicon Surface Fabricated with the Arrays of Uniform Inverted Pyramid Microstructures in UV-Visible Range
}

(Ciri Pantulan Permukaan dalam Julat UV-Nampak Bagi Silikon yang Difabrikasi dengan Jajaran Seragam Mikrostruktur Piramid Sonsang)

\author{
Mohd FAizol ABDUllaH \& ABDUl ManAF HASHiM*
}

\begin{abstract}
In this paper, inverted pyramidal microstructures are designed and fabricated on silicon (Si) surface. The characteristics of surface reflectance are simulated using two-dimensional (2D) finite-difference time-domain (FDTD) method by varying the spacing $(S)$ and width $(W)$ of the pyramidal microstructures. The results showed that the effect of $S$ is more significant compared to $W$ where the reflectance of the irradiated light has been increased gradually with the increase of $S$ from 0 to $3 \mu \mathrm{m}$, and the difference is around 9.6\%. Due to the etching constraint, $S=3 \mu \mathrm{m}$ is chosen for the fabrication. Textured structure is fabricated by the anisotropic etching of tetramethyl-ammonium hydroxide (TMAH) with additional of isopropyl alcohol (IPA). Long etching time of $120 \mathrm{~min}$ is required to form uniform arrays of pyramidal microstructures with smooth and well-terminated four sidewalls at (111) plane. Due to the undercut etching under $\mathrm{SiO}_{2}$ mask, it results to the formation of slightly larger $W$ and smaller $S$ in the fabricated structures. The measured average reflectance in UVvisible range for the Si with inverted pyramidal microstructures is very low down to $10.4 \%$. The discrepancy between the measured and simulated values is speculated to be due to the use of 2D FDTD instead of three-dimensional (3D) FDTD.
\end{abstract}

Keywords: Anisotropic etching; FDTD; reflectance; Si inverted pyramid; TMAH/IPA; UV-visible

ABSTRAK

Dalam kertas ini, mikrostruktur piramid songsang Si bersaiz mikro telah direka bentuk dan difabrikasi di atas permukaan silikon (Si). Ciri pantulan permukaan telah disimulasi menggunakan kaedah domain-masa perbezaan-terhingga (FDTD) dua-dimensi (2D) dengan membezakan jarak dan lebar mikrostruktur piramid. Data menunjukkan kesan jarak (S) adalah lebih ketara jika dibandingkan dengan kesan lebar $(W)$ terhadap pantulan permukaan. Pantulan cahaya yang disinarkan telah meningkat secara beransur-ansur dengan peningkatan $S$ daripada 0 kepada 3 um dan perbezaan adalah sekitar 9.6\%. Disebabkan kekangan punaran, $S=3 \mu$ m telah dipilih untuk difabrikasi. Tekstur telah difabrikasi dengan cara punaran anisotropik oleh tetra metil ammonium hidroksida (TMAH) berserta campuran alkohol isopropil (IPA). Punaran pada tempoh yang lama iaitu 120 min diperlukan untuk membentuk jajaran mikrostruktur piramid yang seragam dengan empat sisi tepi pada satah (111) yang licin berserta penamatan yang baik. Disebabkan potongan bawah punaran di bawah topeng $\mathrm{SiO}_{2}$, ia membentuk Wyang sedikit lebih besar dan $\mathrm{S}$ yang lebih kecil bagi struktur yang telah difabrikasi. Purata pantulan dalam julat UV-nampak yang telah diukur bagi Si dengan mikrostruktur piramid songsang adalah sangat rendah iaitu 10.4\%. Percanggahan antara nilai yang diukur dengan nilai yang disimulasi telah dispekulasi disebabkan penggunaan FDTD 2D dan bukannya FDTD tiga-dimensi (3D).

Kata kunci: FDTD; pantulan; piramid songsang Si; punaran anisotropik; TMAH/IPA; UV-nampak

\section{INTRODUCTION}

The introduction of micro-scale textured structures on Si surface is important to reduce the light reflectance. By lowering a front surface reflectance, a greater light absorption in Si can be achieved which is necessary to increase the performance of devices such as solar cell. Surface texturing is obtainable by either isotropic or anisotropic etching of the patterned surface. The isotropic etching removes the exposed area at similar rate without any preferred direction and it is popular for making textured structures on polycrystalline Si (Macdonald et al. 2004). Whereas, the anisotropic etching is a directiondependence, where the alkaline wet etchants such as potassium hydroxide $(\mathrm{KOH})$ and sodium hydroxide $(\mathrm{NaOH})$ are used to etch $\mathrm{Si}$ with higher rate in $<100>$ and $<110>$ directions (Park et al. 2009; Sepeai et al. 2017; Xi et al. 2004). Here, the ionized $\mathrm{KOH}$ and $\mathrm{NaOH}$ generate hydroxyl ions which are responsible for the etching of Si.

The other commonly used etchant for Si substrate is tetramethyl-ammonium-hydroxide (TMAH) (You et al. 2001). However, the cost of TMAH is much more expensive as compared with $\mathrm{KOH}$ and $\mathrm{NaOH}$. The advantages of using TMAH are: A less residue contamination of $\mathrm{K}^{+}$and $\mathrm{Na}^{+}$ions on the textured surface (Abdullah et al. 2016), a capability in producing uniform micro-textured structures (Iencinella et al. 2004), and only a low concentration of 
TMAH is required for the etching of Si surface (Abdullah et al. 2016). The introduction of surfactant such as isopropyl alcohol (IPA) in TMAH can further improve the uniformity and shape of micro-textured structures (Ou et al. 2011; Papet et al. 2006). By introducing $\mathrm{SiO}_{2}$ patterned mask structure on Si surface, the inverted micro-textured structures can be produced (Fan et al. 2013). Inverted micro-textured structure is much more effective in reducing light reflectance and increasing light confinement for $\mathrm{Si}$ solar cell where relatively high efficiency of $25 \%$ has been achieved (Green et al. 2018, 2001).

In this work, a simulation of the optical characteristics of the designed $\mathrm{Si}$ inverted pyramidal microstructures is presented. Here, the light propagation is simulated using software package based on finite-difference time-domain (FDTD) method (Abdullah \& Hashim 2018; Jamil et al. 2018), which is simple yet precise as compared to rigorous coupled-wave approach (Shuba et al. 2015; Solano et al. 2013). The fabrication of the arrays of Si inverted pyramidal microstructures by wet etching using a mixture of TMAH and IPA is carried out. The morphology of inverted pyramidal microstructures is evaluated and the surface reflectance is measured and compared with the simulation results.

\section{SIMULATION}

Two-dimensional (2D) Si inverted pyramidal microstructures are designed and their optical characteristics are simulated using a commercial Lumerical FDTD software. The refractive index and permittivity of Si are referred to Palik's handbook (Palik 1998). The inverted pyramidal microstructure is defined by three parameters, width $(W)$, depth $(D)$ and spacing $(S)$ as shown in Figure 1(a). The values of $W$ are varied in the range of 1-10 $\mu \mathrm{m}$, while the values of $D$ are set using a relationship of $D=(W / 2)$ tan $54.7^{\circ}$. Here, $54.7^{\circ}$ is the angle between $<100>$ and $<111>$ in Si crystal (Abdullah et al. 2016). The values of $S$ for the square arrays are varied in range of 0-3 $\mu \mathrm{m}$. Figure 1(b) shows the simulation configuration applied in Lumerical FDTD. The 2D boundary conditions are defined by periodic boundary for both upper and lower $x$-axis, while a perfectly matched layer (PML) boundary for both upper and lower $y$-axis. The plane wave in UV-visible range $(\lambda=300-700 \mathrm{~nm})$ is used as a light source. The plane wave is defined by transverse magnetic (TM) and transverse electric (TE) wave modes to simulate the unpolarized light.

\section{EXPERIMENTAL DETAILS}

The fabrication steps of $\mathrm{Si}$ inverted pyramidal microstructures are summarized in Figure 2(a)-2(f). A $525 \mu \mathrm{m}$-thick $\mathrm{SiO}_{2} / \mathrm{n}$-Si (100) sample cut into $1 \times 1 \mathrm{~cm}^{2}$ is used. The thickness of thermally grown $\mathrm{SiO}_{2}$ is 100 $\mathrm{nm}$ and the bulk resistivity of $\mathrm{Si}(100)$ is $0.3-0.5 \Omega \mathrm{cm}$. Each sample is subjected to ultrasonic organic cleaning in acetone for $5 \mathrm{~min}$ and IPA for $5 \mathrm{~min}$. Sample surface is treated with hexamethyl-disilazine prior to resist coating. Then, undiluted ZEP-520A is spin-coated on the sample at 3,000 rpm for $60 \mathrm{~s}$, followed by a pre-bake on hot plate at $180^{\circ} \mathrm{C}$ for $5 \mathrm{~min}$. The square array is patterned using electron beam lithography (JEOL JBX-6300FS, 100 $\mathrm{kV}$ voltage and $5 \mathrm{nA}$ current, $240 \mu \mathrm{C} / \mathrm{cm}^{2}$ dose) for the area of $5 \times 5 \mathrm{~mm}^{2}$. After exposure, sample is developed in xylene for $60 \mathrm{~s}$, rinsed in IPA for $30 \mathrm{~s}$ and post-baked in oven at $180^{\circ} \mathrm{C}$ for $10 \mathrm{~min}$.

After the pattern development, the sample with the exposed $\mathrm{SiO}_{2}$ is immersed in $10 \%$ hydrofluoric acid for $6 \mathrm{~min}$ and rinsed in de-ionized (DI) water. After that, ZEP-520A resist is removed by methyl ethyl ketone and organic cleaning. The exposed $\mathrm{Si}$ area is etched in a mixture of 5 wt. \% TMAH and 10 vol. $\%$ IPA at $80^{\circ} \mathrm{C}$ for $120 \mathrm{~min}$. During the etching process, a mixture is stirred at $300 \mathrm{rpm}$ using a magnetic stirrer with a top of beaker is re-fluxed. After etching, the sample is rinsed in DI water.

The etching progress of inverted pyramidal microstructures is monitored by a periodical inspection of the surface using metallurgical microscope system (Olympus-BX51M (50× magnification). The higher magnified views of post-etching $\mathrm{Si}$ inverted pyramidal microstructures $(2,000 \times, 6,000 \times$ and $8,000 \times$ magnification) are taken using a field-effect scanning electron microscope (FESEM) (FEI Helios NanoLab G3 $\mathrm{UC})$. The front surface reflectance of the textured $\mathrm{Si}$ surface is measured using UV-vis spectroscope (Shimadzu UV-1800 within $\lambda=300-700 \mathrm{~nm}$ ).

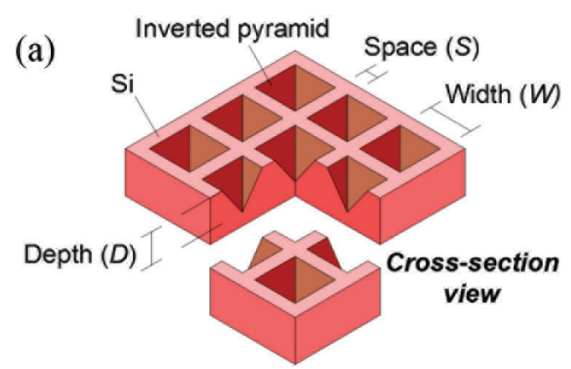

(b)

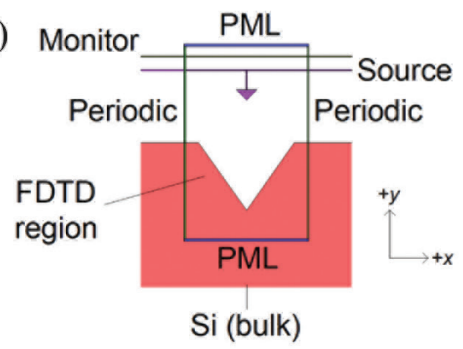

FIGURE 1. Schematic of (a) Si inverted pyramidal microstructure arrays and (b) configuration of FDTD region with PML and periodic boundaries 


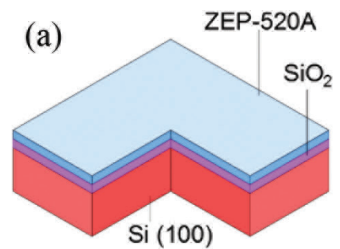

(d)

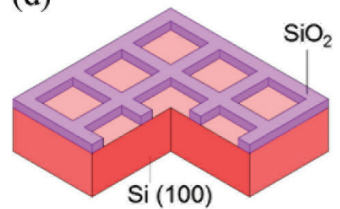

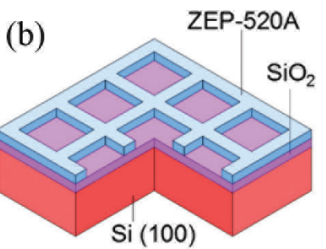

(e)

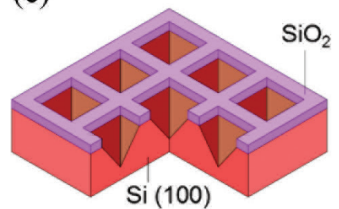

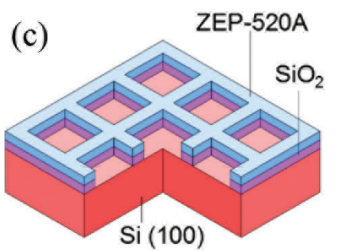

(f)

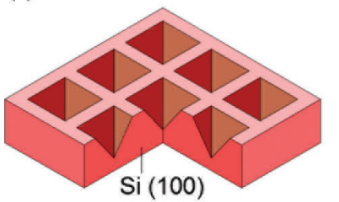

FIGURE 2. Fabrication steps of Si inverted pyramidal structure arrays. (a) coating of ZEP-520A on the $\mathrm{SiO}_{2} / \mathrm{Si}$ (b) exposure and development of pattern (c) etching of the exposed $\mathrm{SiO}_{2}$ (d) removal of ZEP-520A (e) etching of Si in TMAH/IPA and (f) removal of $\mathrm{SiO}_{2}$

\section{RESULTS AND DISCUSSION}

Figure 3(a) shows the simulated average front surface reflectance when $W$ is varied from 1 to $10 \mu \mathrm{m}$ with $S=0$ $\mu \mathrm{m}$, no spacing. It can be seen that there is no significant change of the reflectance since only a slight increment of the average reflectance with the increase of $W$ values. The average reflectance of unpolarized light at $W=1 \mu \mathrm{m}$ and 10 $\mu \mathrm{m}$ are $19.6 \%$ and $21.8 \%$, respectively. The same tendency can be also seen for both TM and TE waves. Figure 3(b) shows the average reflectance when $S$ is varied from 0 to $3 \mu \mathrm{m}$. Here, $W$ is fixed at $10 \mu \mathrm{m}$. It can be clearly seen that by increasing the $S$ values, both TM and TE waves show high increment of average reflectance. The average reflectance of unpolarized light at $S=0 \mu \mathrm{m}$ and $3 \mu \mathrm{m}$ are $21.8 \%$ and $31.4 \%$, respectively, which results to the difference of $9.6 \%$.

As shown by the simulation results, it can be concluded that the effect of $W$ is insignificant as compared to $S$ on the reflectance. However, for the fabrication, $S=3 \mu \mathrm{m}$ is chosen since this dimension would lead to the formation of inverted pyramidal microstructures with high uniformity. Larger size of $S$ dimension means that the dimension of $\mathrm{SiO}_{2}$ mask is larger to withstand the etching as well as to ensure the exposed $\mathrm{Si}$ area can be etched sufficiently in producing excellent inverted pyramidal shape. Here, $W=$ $10 \mu \mathrm{m}$ is chosen.

Figure 4(a)-4(d) shows the images of Si surface after being etched at 30, 60, 90 and $120 \mathrm{~min}$, respectively. As shown in Figure 4(a), after $30 \mathrm{~min}$ etching, a random distribution of small etching spots can be observed at the exposed $\mathrm{Si}$ area. As the etching time is prolonged to $60 \mathrm{~min}$, the arrays of complete inverted pyramidal microstructures can be observed in the exposed area as shown in Figure 4(b). However, there is still many incomplete microstructures can be observed. The number of complete pyramidal microstructures increase when the time is increased to $90 \mathrm{~min}$ as shown in Figure 4(c). After 120 min of etching as shown in Figure 4(d), uniform arrays of complete inverted pyramidal microstructures are observed. The etching rate is very low probably due to the addition of IPA. As being reported, IPA is able to lower the surface tension and liberate water particles in close vicinity to Si surface (Vazsonyi et al. 1999; Zubel \& Kramkowska 2001; Zubel et al. 2011). As a result, except $<100>$ and $<111>$, the overall etching rates in the rest of $<\mathrm{hkl}>$ are lowered (Singh et al. 2001; Zubel \& Kramkowska 2004). The formation of Si inverted pyramidal microstructures according to the respective etching times is also illustrated schematically in Figure 4(a)-4(d) for better understanding.
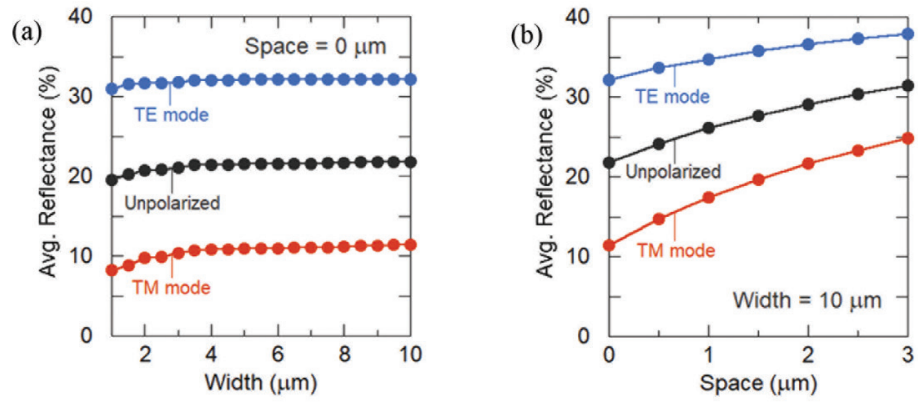

FIGURE 3. The dependency of average reflectance on (a) width and

(b) space of inverted pyramidal structure 


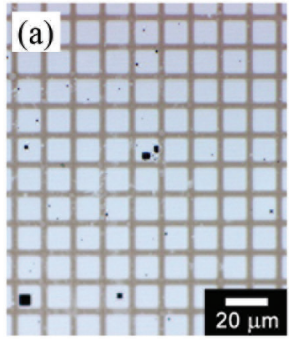

$\mathrm{SiO}_{2}$

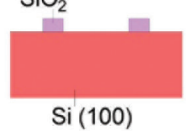

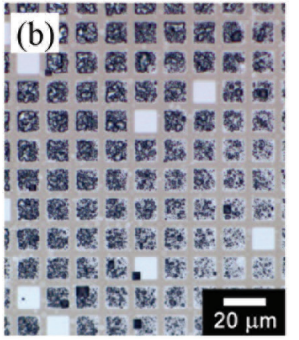

$\mathrm{SiO}_{2} \mathrm{Si}(111)$

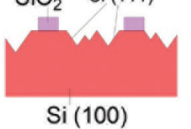

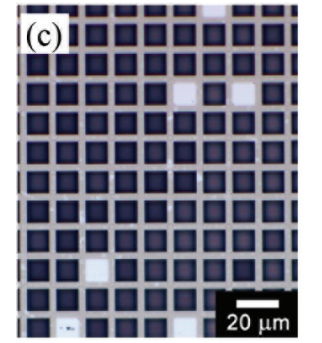

$\mathrm{SiO}_{2} \mathrm{Si}(111)$

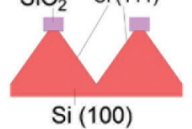

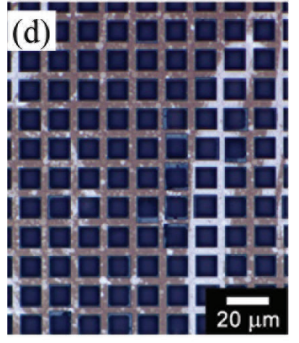

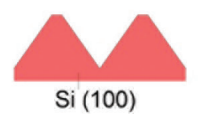

FIGURE 4. Photo images of inverted pyramidal structure arrays after etching for (a) $30 \mathrm{~min}$ (b) $60 \mathrm{~min}$ (c) $90 \mathrm{~min}$ and (d) $120 \mathrm{~min}$. Bottom schematics illustrated the respective etching condition

The preferred TMAH/IPA etching directions are $<100>$ and $<110>$ toward (111) plane which have resulted to the formation of 4 sidewalls of inverted pyramidal microstructures. Figure 5(a) shows the SEM image of Si inverted pyramid array after a removal of $\mathrm{SiO}_{2}$ mask. Due to the undercut under $\mathrm{SiO}_{2}$ during the etching, the final dimensions of $S$ and $W$ of the inverted pyramidal microstructures become slightly different from the original lithography size (Fan et al. 2013). The etching by TMAH/IPA has resulted to a clean and smooth Si (111) sidewall with a sharp vertex as can be seen in Figure 5(b). The undercut gives slightly larger $W$ up to $12 \mu \mathrm{m}$ and smaller $S$ down to $1 \mu \mathrm{m}$. Figure 5(c) shows the cross-sectional image tilted at $60^{\circ}$ of an individual inverted pyramidal structure. Since the inclination of sidewall is constrained at $54.7^{\circ}$, the obtained $D$ of inverted pyramidal structure has been determined to be in the range of 7.1-8.5 $\mu \mathrm{m}$ depending on the final value of $W$.

The spectra of the simulated and measured front surface reflectance in the UV-visible range is shown in Figure 6. Both simulation and measured reflectance show that the surface with inverted pyramidal microstructures significantly reduce the light reflection. The reflection reduces with the increase of light wavelength towards visible range. Table 1 shows the average simulated and measured reflectance for the flat and textured surfaces in UV, visible and UV-visible range.
The simulated average reflectance of the unpolarized light for flat $\mathrm{Si}$ in UV-visible range is $45.9 \%$, while for the surface with inverted pyramidal microstructures is $31.4 \%$. It can be seen that a high portion of light is reflected in UV wave $(\lambda=300-400 \mathrm{~nm})$ as compared to the visible range $(\lambda=400-700 \mathrm{~nm})$ for both surface conditions. The presence of Si inverted pyramidal microstructures has led to the drastic reduction of the average reflectance with the difference of $14.5 \%$ in UV-visible range. The average measured reflectance in UV-visible range for a flat $\mathrm{Si}$ is extremely high with a value of $53.5 \%$. Whereas, the average measured reflectance for the surface with inverted pyramidal microstructures is very small with a value of only $10.4 \%$. The fabricated arrays of inverted pyramidal microstructures have also demonstrated a significant reduction in UV reflectance where almost $50.0 \%$ is shaved off. It can be also understood that approximately $43.1 \%$ reduction of the surface reflectance in UV-visible range is achieved by the Si textured surface.

It can be noticed that there is a significant discrepancy between the simulated and measured values. For the flat $\mathrm{Si}$, the difference of average reflectance in UV-visible range is around $+7.6 \%$, while for $\mathrm{Si}$ with inverted pyramidal microstructures, the difference is $-21.0 \%$. The possible reason for such huge difference is probably due to the use of 2D FDTD simulation instead of three-dimensional (3D) FDTD for the simulation of Si with inverted pyramidal
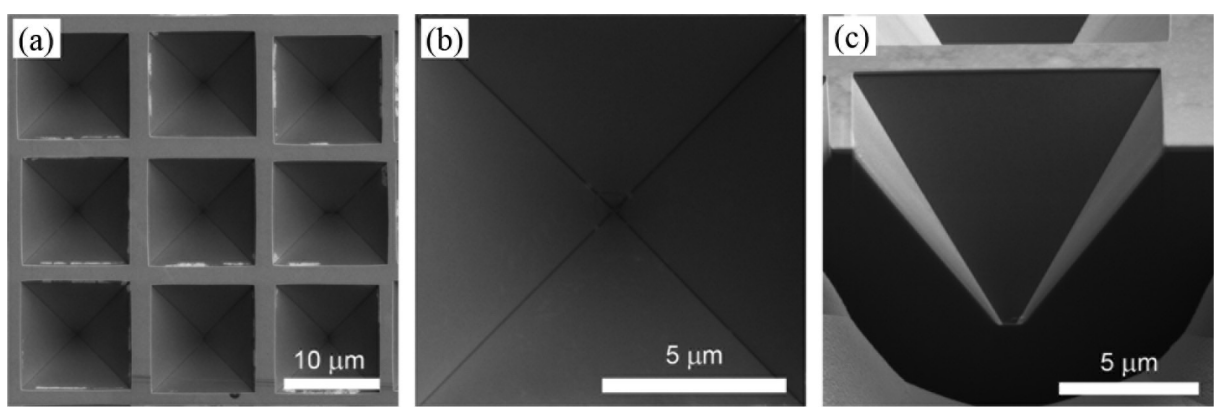

FIGURE 5. SEM images of inverted pyramidal microstructures (a) top view of arrays of inverted pyramidal structures

(b) top view of individual pyramidal structure and (c) cross-sectional view of pyramidal structures tilted at $60^{\circ}$ 


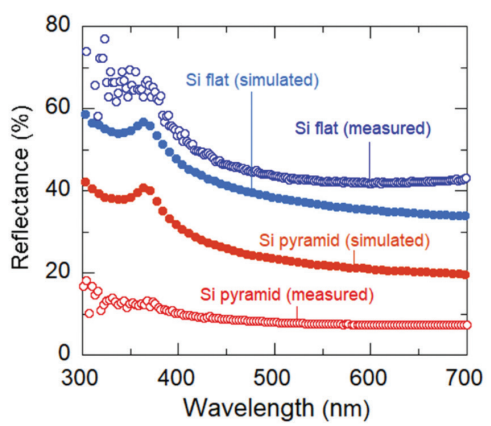

FIGURE 6. Simulated ( $W=10 \mu \mathrm{m}, S=3 \mu \mathrm{m}, D=7.1 \mu \mathrm{m}$ ) and measured ( $W \sim 12 \mu \mathrm{m}, S \sim 1 \mu \mathrm{m}, D \sim 8.5 \mu \mathrm{m}$ ) reflectance of Si with flat surface and inverted pyramidal microstructures in UV-visible range

TABLE 1. Summary of simulated ( $W=10 \mu \mathrm{m}, S=3 \mu \mathrm{m}, D=7.1 \mu \mathrm{m})$ and measured $(W \sim 12 \mu \mathrm{m}, S \sim 1 \mu \mathrm{m}$, $D \sim 8.5 \mu \mathrm{m})$ average reflectance of unpolarized light in UV, visible and UV-visible range

\begin{tabular}{lcccccc}
\hline & \multicolumn{3}{c}{ Simulated average reflectance $(\%)$} & \multicolumn{3}{c}{ Experiment average reflectance (\%) } \\
\cline { 2 - 7 } & Flat & Textured & Difference & Flat & Textured & Difference \\
\hline UV & 54.3 & 39.6 & 14.7 & 62.9 & 12.9 & 50.0 \\
Visible & 37.5 & 23.1 & 14.4 & 44.0 & 7.9 & 36.1 \\
UV-visible & 45.9 & 31.4 & 14.5 & 53.5 & 10.4 & 43.1 \\
\hline
\end{tabular}

microstructure and the changes in $W$ and $S$ dimension after the fabrication of inverted pyramidal microstructures. The first factor is a common limitation since large feature consume lots of computational resources and time. 3D modelling and FDTD simulation for large area involves multiplication of mesh points to store the material and geometrical information for solving the electric and magnetic field propagation. With this reason, to the best of our knowledge, the work using 3D FDTD for such calculation is never being reported. It is worth to note that by using 2D FDTD, the simulated structure in this work can be ambiguously represented by one V-groove structure instead of inverted pyramidal structure. Figure 7(a) and 7(b) shows the illustration of reflectance suppression by a V-groove structure and an inverted pyramidal structure, respectively. It can be understood that the inverted pyramidal microstructure can be basically built by combining two perpendicular V-groove structures. The presence of perpendicular two inclined surfaces of $\mathrm{Si}$ (111) in inverted pyramidal structure should increase the neighboring light reflection, thus, lowering the reflectance compared to one V-groove structure. Referring to the simulated and measured reflectance shown in Figure 6, we can observe a simple trend where the reflectance of the fabricated inverted pyramidal structure is almost half of the value of 2D FDTD. Here, it is speculated that the total reflectance given by two V-groove structures should approach the measured value of the inverted pyramidal structure.

Another factor which is the changes in $W$ and $S$ dimension after the fabrication of inverted pyramidal microstructures, however seems to give a minor effect on that discrepancy between the simulated and measured reflectance. Surface reflectance is reduced by the inclined surfaces of Si (111) before travelling and being absorbed into the bulk Si (Abdullah et al. 2016). Since the studied structure is considered larger than the incident light wavelength, the change of $W$ in micrometer-scale does not induce a significant difference on the reflectance. If larger range of $W$ is studied which is extending down to submicron and nanometer-scale, then a significant difference on the reflectance can be expected due to the
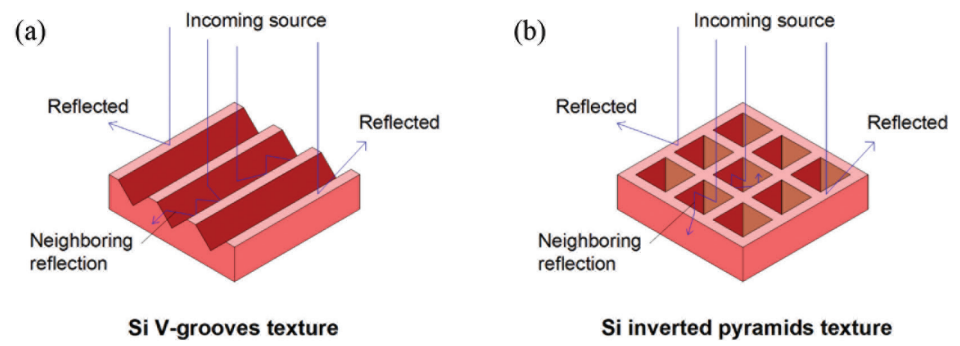

FIGURE 7. Illustration of optical loss reduction by promoting neighboring reflection on $\mathrm{Si}$

(a) V-groove structure and (b) inverted pyramidal structure 
TABLE 2. Comparison of the reported reflectance on Si inverted pyramidal structures

\begin{tabular}{cccl}
\hline Width, $W$ & Spacing, $S$ & Average reflectance & \multicolumn{1}{c}{ Reference } \\
\hline $1-5 \mu \mathrm{m}$ & Random & $\sim 14 \%$ in $400-1100 \mathrm{~nm}$ & Kim et al. (2010) \\
$\sim 10 \mu \mathrm{m}$ & $1.96 \mu \mathrm{m}$ & $13.1 \%$ in $350-1150 \mathrm{~nm}$ & Fan et al. (2013) \\
$1-5 \mu \mathrm{m}$ & Random & $17.3 \%$ in 300-1100 nm & Saseendran et al. (2015) \\
$1-5 \mu \mathrm{m}$ & Random & $\sim 12 \%$ in 300-1000 nm & Yang et al. (2017) \\
$0.4-0.5 \mu \mathrm{m}$ & Random & $13 \%$ in $400-1200 \mathrm{~nm}$ & Xu et al. (2018) \\
$\sim 12 \mu \mathrm{m}$ & $\sim 1 \mu \mathrm{m}$ & $10.4 \%$ in 300-700 nm & This work \\
\hline
\end{tabular}

involvement of the light scattering phenomena. Similarly, the changes of $S$ in the studied range is also expected to give a minor effect on that discrepancy between the simulated and measured reflectance.

Table 2 shows the reported reflectance on $\mathrm{Si}$ inverted pyramidal structure in comparison to this work. Kim et al. (2010) obtained $\sim 14 \%$ reflectance by a random texture after TMAH texturization with low quality porous $\mathrm{SiO}_{2}$ mask. Fan et al. (2013) obtained 13.1\% reflectance by a uniform texture after TMAH texturization with photolithography-defined $\mathrm{SiO}_{2}$ mask. Saseendran et al. (2015) obtained $17.3 \%$ reflectance by a random texture after TMAH texturization with blistered $\mathrm{SiN}_{x}$ mask. Yang et al. (2017) obtained $\sim 12 \%$ reflectance by a random texture after applying maskless $\mathrm{Cu}$-assisted KOH/IPA texturization. $\mathrm{Xu}$ et al. (2018) obtained 13\% reflectance by a random texture after using $\mathrm{NaOH}$ texturization inside a random etched nanohole. Compared to all those works even they were averaging the value up to the near-infrared region, the texturization reported in this article has successfully resulted to the lowest reflectance. Thus, it can be speculated that a uniform array of pyramidal structure seems to be more favorable compared to a random pyramidal structure in order to suppress the light reflectance for solar cell application.

\section{CONCLUSION}

The arrays of inverted pyramidal microstructures on $\mathrm{Si}$ surface has been studied for the purpose to increase the light confinement and to reduce reflection. Both simulated and measured reflectance values show that the effect of spacing between the inverted pyramidal microstructure is more significant as compared to a width. The average measured reflectance in UV-visible range for the fabricated Si with inverted pyramidal microstructures is shown to be very low down to $10.4 \%$.

\section{ACKNOWLEDGEMENTS}

M.F. Abdullah thanks Malaysia-Japan International Institute of Technology, Universiti Teknologi Malaysia for the scholarship. This project is financially supported by Universiti Teknologi Malaysia, the Ministry of Education (Malaysia) and the Ministry of Science, Technology and Innovation (Malaysia) through various research grants.

\section{REFERENCES}

Abdullah, M.F. \& Hashim, A.M. 2018. Design of optimum rear passivated submicron Al corrugation in very thin textured silicon back-contact back-junction solar cell for absorption enhancement up to near-infrared region. J. Photon. Energy 8: 014501.

Abdullah, M.F., Alghoul, M.A., Naser, H., Asim, N., Ahmadi, S., Yatim, B. \& Sopian, K. 2016. Research and development efforts on texturization to reduce the optical losses at front surface of silicon solar cell. Renew. Sustainable Energy Rev. 66: 380-398.

Fan, Y., Han, P., Liang, P., Xing, Y., Ye, Z. \& Hu, S. 2013. Differences in etching characteristics of TMAH and $\mathrm{KOH}$ on preparing inverted pyramids for silicon solar cells. Appl. Surf. Sci. 264: 761-766.

Green, M.A., Hishikawa, Y., Dunlop, E.D., Levi, D.H., HohlEbinger, J. \& Ho-Baillie, A.W.Y. 2018. Solar cell efficiency tables (version 52). Prog. Photovolt. Res. Appl. 26: 427-436.

Green, M.A., Zhao, J., Wang, A. \& Wenham, S.R. 2001. Progress and outlook for high-efficiency crystalline silicon solar cells. Sol. Energ. Mat. Sol. Cells 65: 9-16.

Iencinella, D., Centurioni, E., Rizzoli, R. \& Zignani, F. 2004. An optimized texturing process for silicon solar cell substrates using TMAH. Sol. Energ. Mat. Sol. Cells 87: 725-732.

Jamil, N.A., Susthitha Menon, P., Mei, G.S. \& Yeop Majlis, B. 2018. Peningkatan kepekaan biosensor urea berasaskan resonans plasmon permukaan dan tatasusunan Kretschmann dengan struktur hibrid grafin-mos ${ }_{2}$. Sains Malaysiana 47(5): 1033-1038.

Kim, J., Inns, D., Fogel, K. \& Sadana, D.K. 2010. Surface texturing of single-crystalline silicon solar cells using low density $\mathrm{SiO}_{2}$ films as an anisotropic etch mask. Sol. Energ. Mat. So. Cells 94: 2091-2093.

Macdonald, D.H., Cuevas, A., Kerr, M.J., Samundsett, C., Ruby, D., Winderbaum, S. \& Leo, A. 2004. Texturing industrial multi crystalline silicon solar cells. Sol. Energy 76: 277-283.

Ou, W., Zhang, Y., Li, H., Zhao, L., Zhou, C., Diao, H., Liu, M., Lu, W., Zhang, J. \& Wang, W. 2011. Effects of IPA on texturing process for mono-crystalline silicon solar cell in TMAH solution. Mater. Sci. Forum 685: 31-37.

Palik, E.D. 1998. Handbook of Optical Constants of Solids. New York: Academic Press.

Papet, P., Nichiporuk, O., Kaminski, A., Rozier, Y., Kraiem, J., Lelievre, J.F., Chaumartin, A., Fave, A. \& Lemiti, M. 2006. Pyramidal texturing of silicon solar cell with TMAH chemical anisotropic etching. Sol. Energ. Mat. Sol. Cells 90: 2319-2328.

Park, H., Lee, J.S., Lim, H.J., Kim, D., Kwon, S. \& Yoon, S. 2009. The effect of tertiary-butyl alcohol on the texturing of crystalline silicon solar cells. J. Korean Phys. Soc. 55: 1767-1771. 
Saseendran, S.S. \& Kottantharayil, A. 2015. Inverted pyramidal texturing of silicon through blisters in silicon nitride. IEEE J. Photovolt. 5: 819-825.

Sepeai, S., Zulhafizhazuan, W., Leong, C.S., Ludin, N.A., Ibrahim, M.A., Sopian, K. \& Zaidi, S.H. 2017. Analisis arus-voltan bagi pengubahsuaian proses fabrikasi sel suria silikon jenis-p ke atas wafer silikon jenis-n. Sains Malaysiana 46(10): 1943-1949.

Shuba, M.V., Faryad, M., Solano, M.E., Monk, P.B. \& Lakhtakia, A. 2015. Adequacy of the rigorous coupled-wave approach for thin-film silicon solar cells with periodically corrugated metallic backreflectors: Spectral analysis. J. Opt. Soc. Am. A 32: 1222-1230.

Singh, P.K., Kumar, R., Lal, M., Singh, S.N. \& Das, B.K. 2001. Effectiveness of anisotropic etching of silicon in aqueous alkaline solutions. Sol. Energ. Mat. Sol. Cells 70: 103-113.

Solano, M., Faryad, M., Hall, A.S., Mallouk, T.E., Monk, P.B. \& Lakhtakia, A. 2013. Optimization of the absorption efficiency of an amorphous silicon thin-film tandem solar cell backed by a metallic surface-relief grating. Appl. Opt. 52: 966-979.

Vazsonyi, E., De Clercq, K., Einhaus, R., Van Kerschaver, E., Said, K., Poortmans, J., Szlufcik, J. \& Nijs, J. 1999. Improved anisotropic etching process for industrial texturing of silicon solar cells. Sol. Energ. Mat. Sol. Cells 57: 179-188.

Xi, Z., Yang, D., Dan, W., Jun, C., Li, X. \& Que, D. 2004. Investigation of texturization for monocrystalline silicon solar cells with different kinds of alkaline. Renew. Energ. 29: 2101-2107.

Xu, H., Zhong, S., Zhuang, Y. \& Shen, W. 2018. Controllable nanoscale inverted pyramids for high-efficient quasiomnidirectional crystalline silicon solar cells. Nanotechnology 29: 015403.

Yang, L., Liu, Y., Wang, Y., Chen, W., Chen, Q., Wu, J., Kuznetsov, A. \& Du, X. 2017. 18.87\%-efficient inverted pyramid structured silicon solar cell by one-step Cu-assisted texturization technique. Sol. Energ. Mat. Sol. Cells 166: 121-126.
You, J.S., Kim, D., Huh, J.Y., Park, H.J., Pak, J.J. \& Kang, C.S. 2001. Experiments on anisotropic etching of Si in TMAH. Sol. Energ. Mat. Sol. Cells 66: 37-44.

Zubel, I. \& Kramkowska, M. 2004. Etch rates and morphology of silicon (hkl) surfaces etched in $\mathrm{KOH}$ and $\mathrm{KOH}$ saturated with isopropanol solutions. Sens. Actuator A-Phys. 115: 549-556.

Zubel, I. \& Kramkowska, M. 2001. The effect of isopropyl alcohol on etching rate and roughness of (100) Si surface etched in $\mathrm{KOH}$ and TMAH solutions. Sens. Actuators A-Phys. 93: 138-147.

Zubel, I., Rola, K. \& Kramkowska, M. 2011. The effect of isopropyl alcohol concentration on the etching process of Si-substrates in KOH solutions. Sens. Actuator A-Phys. 171: 436-445.

Malaysia-Japan International Institute of Technology Universiti Teknologi Malaysia

Jalan Sultan Yahya Petra

54100 Kuala Lumpur, Federal Territory

Malaysia

*Corresponding author; email: abdmanaf@utm.my

Received: 16 July 2018

Accepted: 15 November 2018 